Article

\title{
Exploring Charged Polymeric Cyclodextrins for Biomedical Applications
}

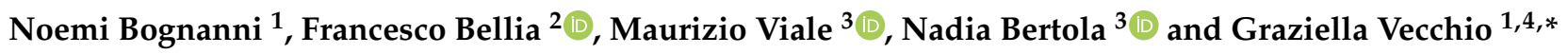 \\ 1 Dipartimento di Scienze Chimiche, Università degli Studi di Catania, Viale A. Doria 6, 95125 Catania, Italy; \\ noemibognanni91@gmail.com \\ 2 Istituto di Cristallografia, CNR, via P. Gaifami 18, 95126 Catania, Italy; francesco.bellia@cnr.it \\ 3 IRCCS Ospedale Policlinico San Martino, U.O.C. Bioterapie, L.go R. Benzi 10, 16132 Genova, Italy; \\ maurizio.viale@hsanmartino.it (M.V.); nadia.bertola@gmail.com (N.B.) \\ 4 Consorzio Interuniversitario di Ricerca in Chimica dei Metalli nei Sistemi Biologici (CIRCMSB), \\ via Celso Ulpiani, 27, 70126 Bari, Italy \\ * Correspondence: gr.vecchio@unict.it; Tel.: +39-9-5738-5064
}

check for updates

Citation: Bognanni, N.; Bellia, F.; Viale, M.; Bertola, N.; Vecchio, G. Exploring Charged Polymeric Cyclodextrins for Biomedical Applications. Molecules 2021, 26, 1724 https: / / doi.org/10.3390/ molecules26061724

Academic Editors: Marina Isidori, Margherita Lavorgna and Rosa Iacovino

Received: 13 February 2021

Accepted: 16 March 2021

Published: 19 March 2021

Publisher's Note: MDPI stays neutral with regard to jurisdictional claims in published maps and institutional affiliations.

Copyright: (c) 2021 by the authors. Licensee MDPI, Basel, Switzerland. This article is an open access article distributed under the terms and conditions of the Creative Commons Attribution (CC BY) license (https:/ / creativecommons.org/licenses/by/ $4.0 /)$.

\begin{abstract}
Over the years, cyclodextrin uses have been widely reviewed and their proprieties provide a very attractive approach in different biomedical applications. Cyclodextrins, due to their characteristics, are used to transport drugs and have also been studied as molecular chaperones with potential application in protein misfolding diseases. In this study, we designed cyclodextrin polymers containing different contents of $\beta$ - or $\gamma$-cyclodextrin, and a different number of guanidinium positive charges. This allowed exploration of the influence of the charge in delivering a drug and the effect in the protein anti-aggregant ability. The polymers inhibit Amiloid $\beta$ peptide aggregation; such an ability is modulated by both the type of $\mathrm{CyD}$ cavity and the number of charges. We also explored the effect of the new polymers as drug carriers. We tested the Doxorubicin toxicity in different cell lines, A2780, A549, MDA-MB-231 in the presence of the polymers. Data show that the polymers based on $\gamma$-cyclodextrin modified the cytotoxicity of doxorubicin in the A2780 cell line.
\end{abstract}

Keywords: aggregation; cancer; doxorubicin; nanoparticles

\section{Introduction}

Cyclodextrins (CyDs) are cyclic oligosaccharides of $\alpha-1,4-$ linked $\mathrm{D}(+)$-glucopyranose with the unique property to act as molecular containers. They have been used in biomedical applications for their ability to include drugs or several biomolecules, such as cholesterol [1-4].

CyD properties can be modulated through their chemical modification. In recent years, CyDs represented an important nanocarrier family, thus developing into sophisticated drug delivery systems [5-7]. Nanoparticles based on CyD, have allowed encapsulation of drugs to protect them and improve their bioavailability. These systems have higher stability constants than those of the corresponding $\mathrm{CyD}$ monomers; they show excellent properties in drug release kinetics, mechanical properties and stimuli-responsiveness [8-11]. Furthermore, these polymeric systems can be used in a clinical setting, such as controlled drug and gene delivery systems [12]. Successful examples of linear CyD polymers specifically designed as drug carriers are Cyclosert and CALAA-01 [13]. CyD polymers modified with choline, amino or carboxylic groups have been investigated to increase their drug loading ability.

Due to the ability to include aromatic molecules of appropriate sizes, CyDs have also been investigated as protein chaperones [14-16]. $\beta$-CyD reduced the $\beta$-amyloid aggregation in vitro at millimolar concentration. The protective effects of $\beta$-CyD were also proven in vivo. The interaction between Amyloid beta peptide (A $\beta)$ and $\alpha-, \beta-$ and $\gamma-\mathrm{CyD}$ was correlated to the ability to include Phe19 and Phe20 side chain of $A \beta$ [16]. Other studies have suggested the higher antiaggregant activity of some functionalised CyDs with 
aromatic moieties [17]. CyD dimers were also found to act as inhibitors of $A \beta_{40}$ aggregation at $1 \mathrm{mM}$ concentration $[18,19]$. We investigated amino-cyclodextrin oligomers as promising $\mathrm{CyD}$ derivatives in inhibiting the aggregation of $\mathrm{A} \beta$ at micromolar concentration [20].

Inspired by the properties of multi-cavity systems and the importance of functionalisation to improve $\mathrm{CyD}$ properties, in this paper we report the synthesis of new linear polymers of $\beta$ - and $\gamma$-CyD with different contents of guanidinium positive charge and number of $\mathrm{CyD}$ cavities. We also assayed the polymer systems as antiaggregant agents and as drug carriers to explore the effects of multi-cavity systems and their functionalisation for biological applications (Figure 1).

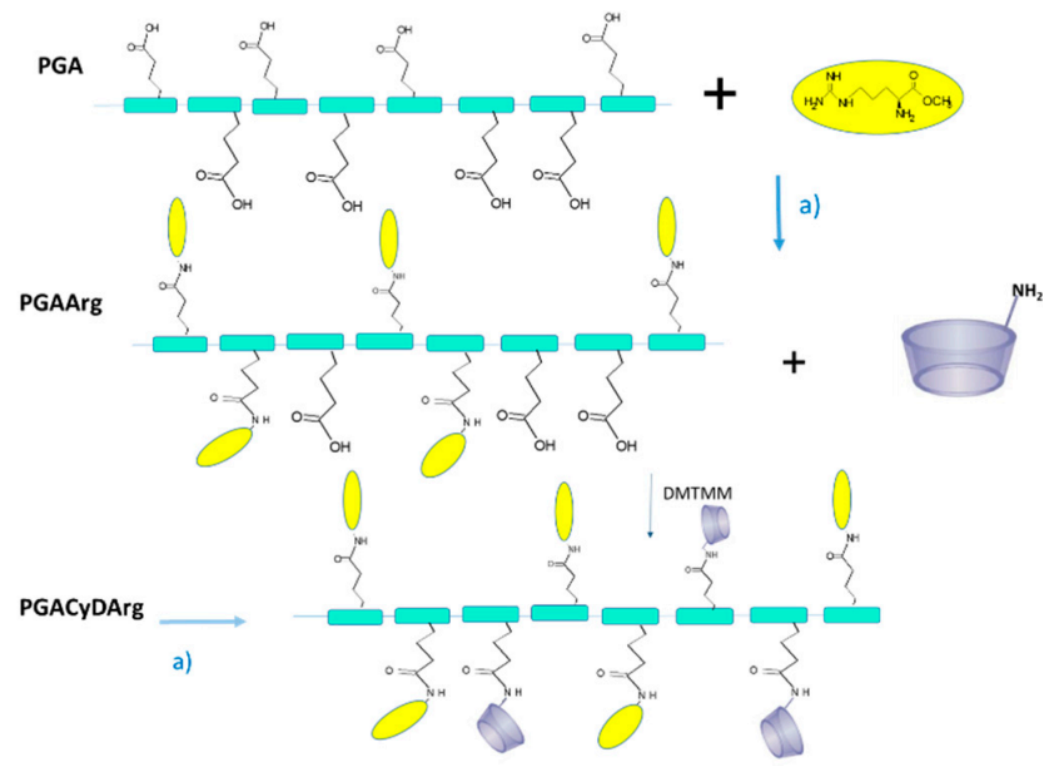

Figure 1. PGA-cyclodextrin (CyD)-Arg polymers, PGA is N-butyl-polyglutamate, a) 4-(4,6Dimethoxy-1,3,5-triazin 2-yl)-4-methylmorpholinium chloride (DMTMM), $\mathrm{H}_{2} \mathrm{O}$ pH 8, rt, 12 h.

It is well known that cancer cells have a deficiency of Arg amino acid and their requirement for arginine is higher than that for other amino acids. Certain tumours lose the ability to synthesise arginine dependently. Therefore, arginine depletion can be considered the weak point in cancer treatment for arginine auxotrophic tumours [21,22]. We used doxorubicin (DOX) as a drug model to test the activity of the new CyD derivatives as nanocarriers. Several studies have highlighted that CyDs can stabilise DOX in solution and enhance its dissolution rate $[23,24]$. Complexation of DOX with CyDs can increase permeability across the blood-brain barrier, due to the disruption of the membrane [25].

\section{Results and Discussion}

\subsection{Synthesis and Characterisation}

Charged CyD polymers were synthesised in water, starting from the polypeptide $\mathrm{N}$-butyl-polyglutamate (PGA), $\mathrm{ArgOCH}_{3}$ and $\mathrm{CyD}$ 3-amino derivatives, using 4-(4,6Dimethoxy-1,3,5-triazin 2-yl)-4-methylmorpholinium chloride (DMTMM) as the condensing agent, as reported elsewhere [26]. We found that this method gave high conjugation yield using a green synthetic route. This procedure is appropriate for modulating the number of CyD cavities and charged groups of Arg in the PGA backbond [27].

We synthesised various polymers with different amounts of Arg and CyD units to explore the effect on polymer properties.

All the new polymers were characterised by NMR (Figures S1-S11). In Figure 2 the NMR spectra of PGA $\beta C y D A r g 1$ and PGA $\beta C y D A r g 4$ are reported. ${ }^{1} \mathrm{H}$ NMR spectra of all the derivatives show common patterns; the protons of $\mathrm{CyD}$ resonate at $5 \mathrm{ppm}(\mathrm{H}-1)$, and 4.0-3.4 ppm (H-3,-6,-5,-4,-2). Protons of arginine and the glutamic acid side chain of PGA resonate at $3.3 \mathrm{ppm}$ and 2.5-1.8 ppm region. Butyl protons of PGA are also evident 
between $1.5 \mathrm{ppm}$ and $1.0 \mathrm{ppm}$. We determined the number of CyD units linked to the PGA backbone for each polymer derivative by calculating the integral ratios of the signal of Hs-1 of $\mathrm{CyD}$, the signal of the ethylene chain protons of PGA or the N-buthyl chain protons. Moreover, the integral ratio of signal due to the $\gamma-\mathrm{CH}_{2}$ of Arg moieties at $3.3 \mathrm{ppm}$ and the signals of PGA ethylenic protons or the N-buthyl protons was used to value the number of Arg moieties grafted to the polymer. The results obtained from NMR for each bioconjugate are reported in Table 1.

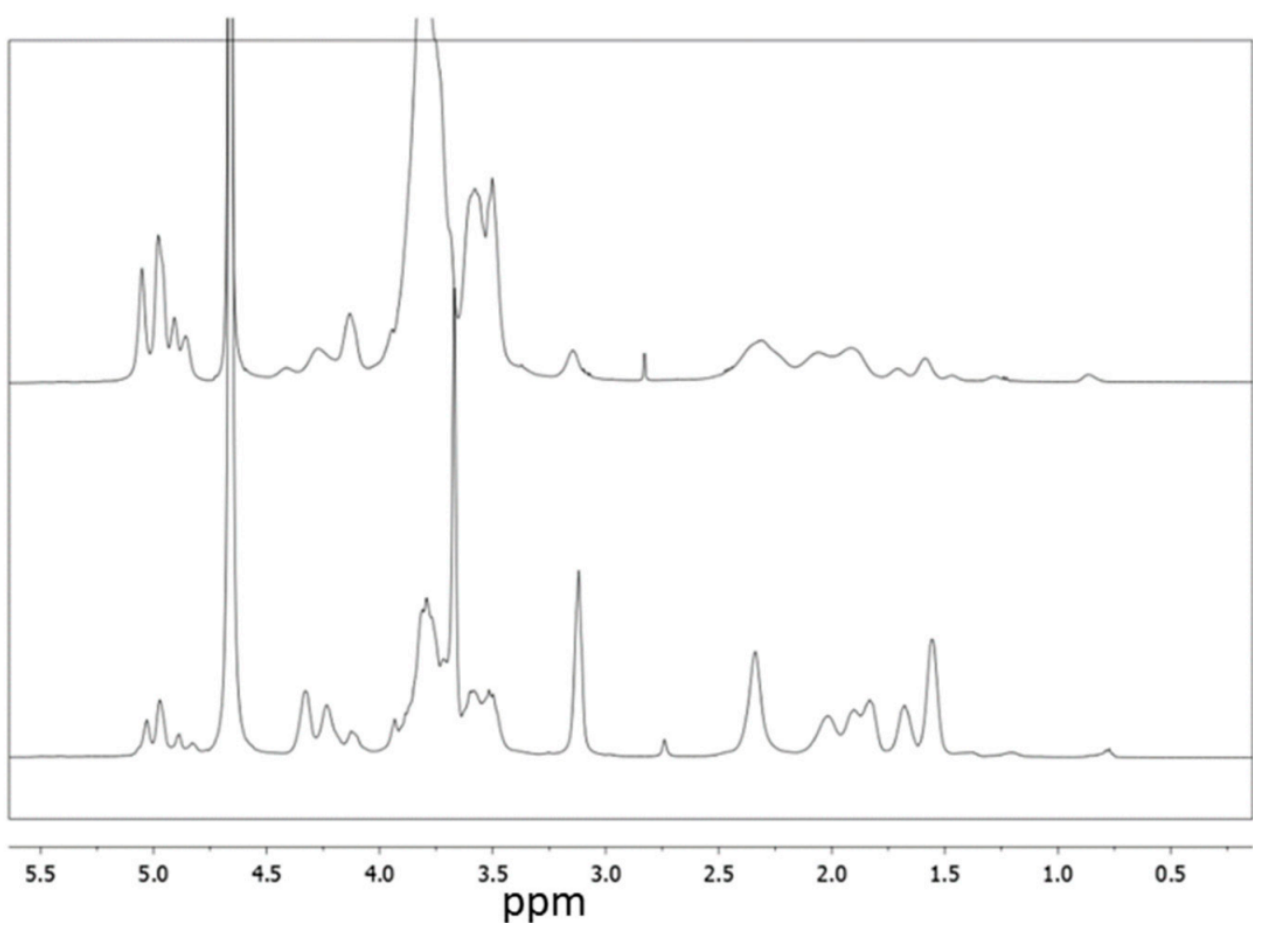

Figure 2. ${ }^{1} \mathrm{H}$ NMR spectra of PGA $\beta$-CyDArg 1 (top), PGA $\beta C y D A r g 4$ (bottom) $\left(\mathrm{D}_{2} \mathrm{O}, 500 \mathrm{MHz}\right.$ ).

Table 1. Features of PGA-CyD-Arg derivatives.

\begin{tabular}{ccccc}
\hline Polymer & CyD Units & Arg Units & Z Potential (mV) & Mw (Da) \\
\hline PGA $\beta$ CyDArg1 & $19 \pm 1$ & $4 \pm 1$ & $8 \pm 1$ & 25,500 \\
PGA $\beta$ CyDArg2 & $15 \pm 1$ & $7 \pm 1$ & $7.7 \pm 0.5$ & 21,700 \\
PGA $\gamma$ CyDArg3 & $12 \pm 1$ & $10 \pm 1$ & $2.3 \pm 0.5$ & 21,100 \\
PGA $\beta$ CyDArg4 & $6 \pm 1$ & $15 \pm 1$ & $45 \pm 5$ & 13,600 \\
PGA $\gamma$ CyDArg5 & $5 \pm 1$ & $15 \pm 1$ & $37 \pm 3$ & 13,300 \\
\hline
\end{tabular}

The ${ }^{13} \mathrm{C}$ NMR spectra of the derivatives show signals due to guanidium carbons at about $160 \mathrm{ppm}$ and signals around $174 \mathrm{ppm}$ due to the carboxyl group of PGA and arginine methyl ester, in addition to the signals of $\mathrm{CyD}$ units in the aliphatic region.

CyD polymers were also characterised by dynamic light scattering (DLS) and Zeta potential values were also measured (Table 1). The hydrodynamic diameters increase with the number of cavities linked to the PGA backbone. The $\mathrm{Z}$ potential values increased when the number of Arg units increased from negative values ( $-58 \mathrm{mV}$ for PGA alone) to positive values, in keeping with the progressive increase in positive charges due to the guanidinium groups.

Spectrometric measurements were also carried out further to characterise the structural features of the new polymers. The MALDI spectra recorded in linear mode (Figure S12) mainly contain a wideband; the $m / z$ values of the highest peaks match to those obtained by the NMR studies (Table 1), within the experimental errors, thus confirming the calculated molecular weight $(\mathrm{Mw})$ of the new CyD polymers. 
As for PGA $\beta$ CyDArg1, the MALDI spectrum is resolved into several components (Figure 3). The average difference between two successive relative peaks is $1280 \pm 20$. This value suggests that the repeat unit contains both the CyD (MW 1135) and glutamic acid (MW 147) moieties, as expected.

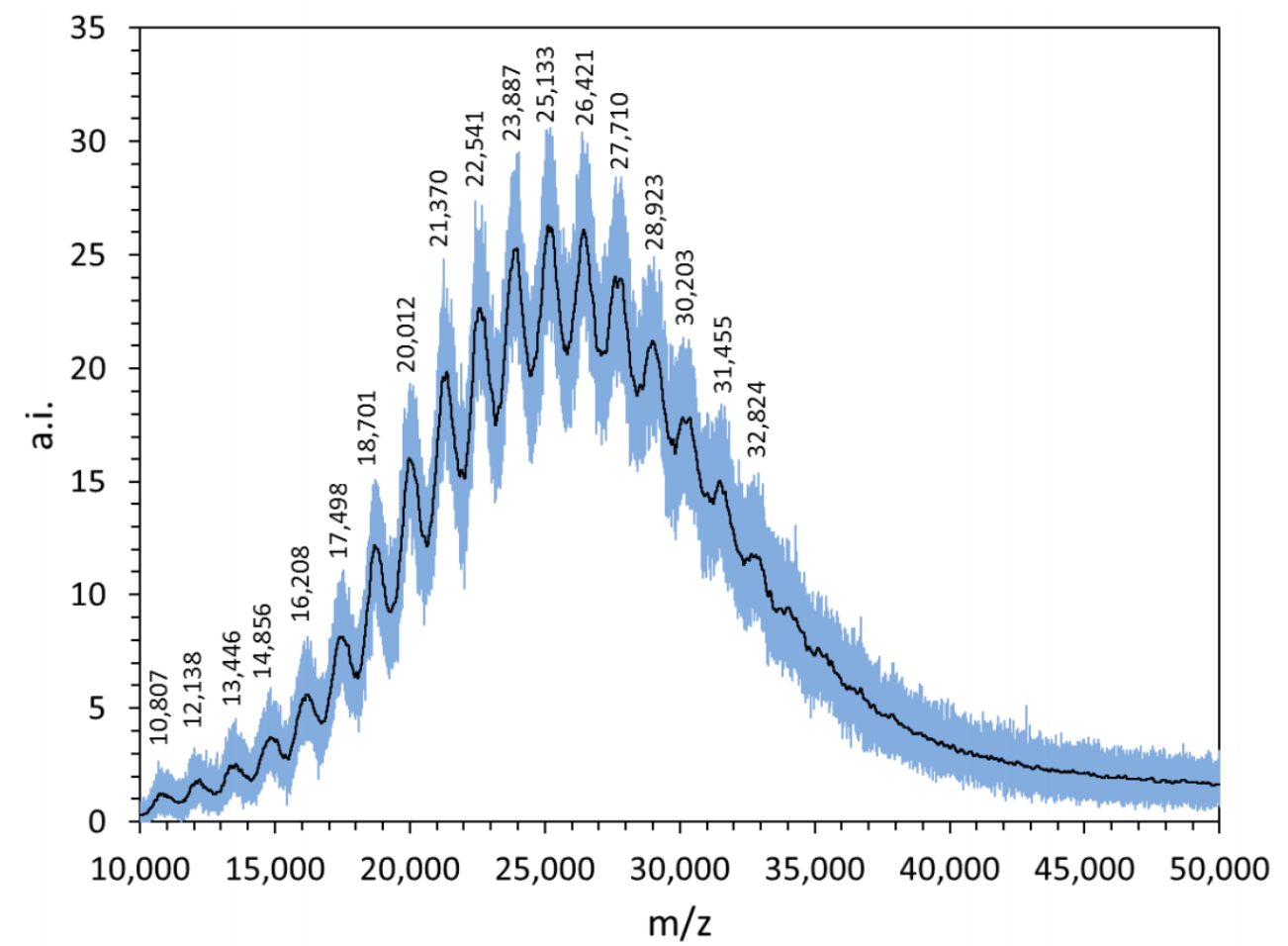

Figure 3. MALDI-TOF MS spectrum of PGA $\beta$ CyDArg1. The raw spectrum (gray line) was properly smoothed (black line) in order to obtain the $m / z$ values of all the relative peaks.

\subsection{Antiaggregant Activity}

The abnormal aggregation of $\mathrm{A} \beta$ is one of the main hallmarks of Alzheimer's disease (AD). In the pathological pathway, the amyloid peptide firstly forms soluble and highly toxic oligomers; then, the growing dimensions of the aggregated species lead to the formation of fibrillary and insoluble structures, mainly accumulated into brain plaques [28]. Finding new molecules able to inhibit the formation of amyloid-type aggregates represents an important strategy to prevent the onset of AD or attenuate the development of this devastating disorder. Therefore, we tested the effect of all the PGA polymers on the selfinduced aggregation of $\mathrm{A} \beta$ by using a turn-on fluorescent dye Thioflavin $\mathrm{T}$ (ThT), sensitive to the formation of fibril species.

The fluorescence data recorded for the amyloid-type aggregation of $A \beta$ fit to a sigmoid curve. The maximum fluorescence gain $\left(F_{\max }-F_{0}\right)$ is $33 \pm 1$ and the lag phase lasts $24 \pm 2 \mathrm{~h}$. When the compounds of interest are co-incubated with $\mathrm{A} \beta$, the kinetic parameters of the aggregation process could be modified due to non-covalent interactions between $\mathrm{A} \beta$ and the PGA polymers. $F_{\max }-F_{0}$ is proportional to the amount of $A \beta$ fibrils, whereas during the lag phase $\left(t_{\text {lag }}\right)$ only small aggregated species form. As a consequence, the lower $F_{\max }-F_{0}$ is and/or the higher $t_{\text {lag }}$ is, the better the antiaggregant activity.

Figure 4 shows the $F_{\max }-F_{0}$ values obtained by the aggregation of $\mathrm{A} \beta$ alone (control (CTRL)) or in the presence of each PGA polymer. Several amounts of the compounds have been tested, the $(\mathrm{A} \beta) /($ Polymer) molar ratio ranging from 1:1 to 1:8. 


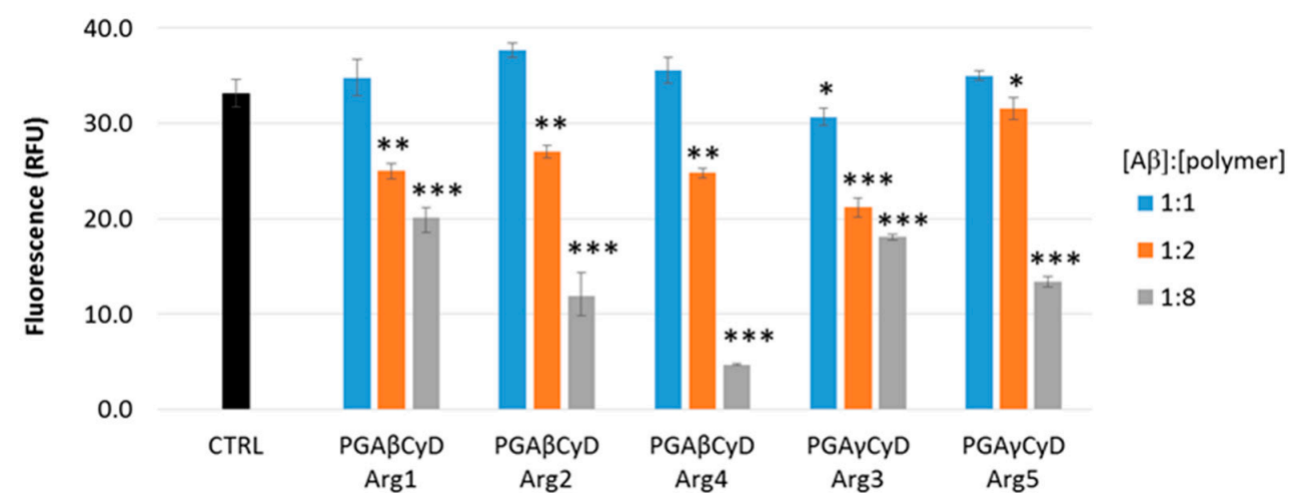

Figure 4. Maximum fluorescence gain values $\left(F_{\max }-F_{0}\right)$ of the samples containing $\mathrm{A} \beta_{1-40}(20 \mu \mathrm{M})$ alone (control (CTRL)) or in the presence of the PGA polymers, the $(\mathrm{A} \beta) /($ Polymer) molar ratio ranging from 1:1 to 1:8. ${ }^{*} p<0.05,{ }^{* *} p<0.01,{ }^{* * *} p<0.001$ vs. CTRL, ANOVA test).

The co-incubation of any polymer with $\mathrm{A} \beta$ in a 1:1 molar ratio induced little or no effect on the final extent of the aggregation process. Higher amounts of the polymers significantly decrease the $F_{\max }-F_{0}$ values and the antiaggregant activity is exerted in a dose-dependent manner, as reported in Figure 5 in the case of PGA $\beta$ CyDArg2.

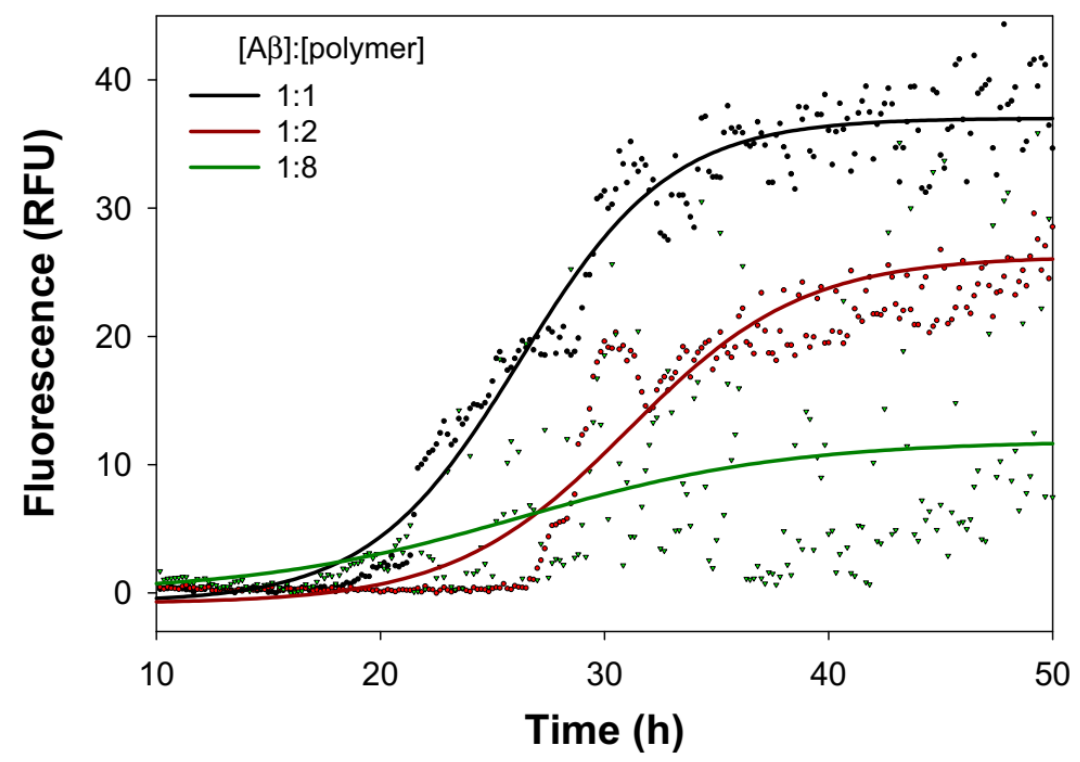

Figure 5. Representative kinetic profiles of the amyloid aggregation due to the co-incubation of $\mathrm{A} \beta_{1-40}(20 \mu \mathrm{M})$ with PGA $\beta$ CyDArg2, the $(\mathrm{A} \beta) /($ Polymer) molar ratio ranging from 1:1 to 1:8. Single points represent the experimental data, whereas the straight lines are the fitted curves (adjusted $\mathrm{R}^{2}$ is $0.9766,0.9481$ and 0.7227 for 1:1, 1:2, 1:8 (A $\beta)$ /(Polymer) molar ratio, respectively).

As for the PGA polymers containing $\beta-\mathrm{CyD}$ (PGA $\beta$ CyDArg1, PGA $\beta$ CyDArg2 and PGA $\beta C y D A r g 4)$, the antiaggregant activity is very comparable among the polymers, when the $A \beta /$ polymer molar ratio was 1:2. Instead, these $\beta-C y D$-containing polymers differently affect the amyloid aggregation extent when the 1:8 $\mathrm{A} \beta$ /polymer molar ratio was tested. In particular, it seems that the greater the number of Arg units, the greater the inhibition effect of the amyloid aggregation. Such a trend is also observed when the $\gamma$-CyD-containing polymers were taken into account (PGA $\gamma$ CyDArg3 and PGA $\gamma$ CyDArg5). However, the inhibition activity of these $\gamma$-CyD polymers is slightly lower than that shown by the corresponding $\beta-C y D$ polymers (PGA $\beta C y D A r g 2$ and PGA $\beta C y D A r g 4)$. Such a difference could be reasonably ascribed to the structural differences between the $\beta$ - and $\gamma$-CyD cavities that, in turn, could affect the non-covalent interaction between the amyloid peptide and the polymers. A similar trend has been reported for single CyDs [14]. 
The lag phase of the amyloid aggregation was not significantly modified by the polymers (data not shown), meaning that the interaction between the $A \beta$ and these PGA polymers is not altered by the number of $\mathrm{CyD}$ and Arg units.

Above all, the antiaggregant activity towards the self-induced formation of amyloid aggregated species exerted by the PGACyD polymers could reasonably be due to the effects of both the CyD cavity and charged units (Arg and PGA). The effect of positive and negative charges of carbohydrate polymers on the on-pathway $A \beta$ aggregation has been recently ascertained [29], thus corroborating these results.

\subsection{Solubility Experiments}

We explored the different affinity of the polymers for the guest DOX by solubility experiments. The effect of the polymers on the solubility can provide a comparison of the affinity for a guest. Data were reported in Figure S13. We found that water solubility of DOX $\left(2.2 \times 10^{-4} \mathrm{M}\right)$ increased in the presence of all the polymers at concentration $25 \mathrm{mg} / \mathrm{mL}$. Particularly the polymers based on $\gamma$-CyD showed an effect higher than that of $\beta$-CyD polymers at physiological ( $\mathrm{pH}$ 7.4). PGA $\gamma \mathrm{CyDArg} 4$ with more $\gamma$-CyD cavities was also more effective than that with a lower numerv of CyDs. This trend is in keeping with the highest affinity of $\gamma \mathrm{CyD}$ cavities for DOX [26,30].

\subsection{Antiproliferative Activity (MTT Assay)}

New polymers were studied as drug delivery systems for the topoisomerase inhibitor DOX. We performed cell proliferation assays on A2780, A549 and MDA-MB-231 cancer cell lines. Complexes polymer/DOX (1:10 molar ratio) were prepared and assayed. Data obtained are reported in Table 2. Polymers alone did not show toxicity for cells (data not shown).

Table 2. Half maximal inhibitory concentration $\left(\mathrm{IC}_{50}\right)$ values $(\mathrm{nM})$ of doxorubicin $(\mathrm{DOX})$ in the presence of CyD polymers in human tumor cells.

\begin{tabular}{|c|c|c|c|c|c|c|}
\hline Cell Line & PGA $\beta C y D A r g 1$ & PGA $\beta$ CyDArg2 & PGA $\gamma$ CyDArg3 & PGA $\beta$ CyDArg 4 & PGA $\gamma$ CyDArg 5 & DOX \\
\hline $\mathrm{A} 2780^{\mathrm{a}}$ & $4.7 \pm 1.7^{b}$ & $5.9 \pm 1.6$ & $12.7 \pm 2.4^{\mathrm{c}}$ & $10.0 \pm 1.7^{\mathrm{d}}$ & $11.7 \pm 0.4^{\mathrm{e}}$ & $7.7 \pm 3.9$ \\
\hline A549 & $55.2 \pm 10.0$ & $52.2 \pm 10.1$ & $70.0 \pm 16.6$ & $52.6 \pm 4.4$ & $56.2 \pm 2.9$ & $54.6 \pm 19.2$ \\
\hline MDA-MB-231 & $37.7 \pm 11.8$ & $40.9 \pm 6.5$ & $50.6 \pm 22.5$ & $60.2 \pm 15.2$ & $65.3 \pm 16.7$ & $40.9 \pm 13.8$ \\
\hline
\end{tabular}

${ }^{\mathrm{a}} p=0.0003$, as detected by ANOVA; ${ }^{\mathrm{b}} p=0.0657$ vs. DOX; ${ }^{\mathrm{c}} p=0.0001$ vs. PGA $\beta$ CyDArg $1{ }^{\mathrm{d}} p=0.0016$ vs. PGA $\beta$ CyDArg1; ${ }^{\mathrm{e}} p=0.0007$ vs. PGA $\beta$ CyDArg1, all calculated by Bonferroni/Dunn post-hoc analysis of data.

Overall, the data show that the polymers did not change the antiproliferative activity of DOX significantly. In fact, in A549 and MDA-MB-231 cell lines, the half maximal inhibitory concentration $\left(\mathrm{IC}_{50}\right)$ values do not change significantly depending on the type of functionalisation. Conversaly, in A2780 cells the complexes with PGA $\gamma$ CyDArg3 $(p=0.0028)$, and PGA $\beta$ CyDArg5 (trend, $p=0.0738$ ) showed higher $\mathrm{IC}_{50}$ values compared to free DOX.

In the case of the polymers based on $\gamma-\mathrm{CyD}$, the higher affinity for DOX suggested by solubility data may explain the effect on the cytotoxicity, as reported for similar systems studied by us [26]. The reduction in the antiproliferative effect was observed for many systems and only in vivo studies may provide information on the potential of the drug carriers [31].

Only PGA $\beta C y D A r g 1 / D O X$ showed a slight trend towards a higher antiproliferative activity $(p=0.0657)$ than free DOX and a significant difference compared to PGA $\gamma C y D A r g 3$, PGA $\gamma$ CyDArg4, and PGA $\beta$ CyDArg5 (Table 2).

\section{Materials and Methods}

\subsection{Materials}

The water-soluble polymer butyl-polyglutamate (20) sodium salt (3 KDa, PGA) was acquired from IRIS Biotech gmbh. 3A-amino-3A-deoxy-2A(S),3A(R)- $\beta$-cyclodextrin $(\beta \mathrm{CyD} 3 \mathrm{NH} 2), 3 \mathrm{~A}$-amino-3A-deoxy-2A(S),3A(R)- $\gamma$-cyclodextrin $(\gamma \mathrm{CyD} 3 \mathrm{NH} 2)$ and DOX 
were acquired from TCI (Tokyo Chemical Industry). L-Arginine methyl ester dihydrochloride was acquired by SIGMA Aldrich. $\mathrm{A} \beta_{1-40}$ (Bachem) was properly treated, as previously reported [32]. Inclusion complexes of DOX with $\mathrm{CyD}$ polymers were prepared by mixing the stock solution of DOX with solutions of CyD polymers for $2 \mathrm{~h}$.

\subsubsection{Synthesis of PGA $\beta C y D A r g 1$}

$\beta C y D 3 \mathrm{NH}_{2}\left(50 \mathrm{mg}\right.$ in $1 \mathrm{~mL}$ of $\mathrm{H}_{2} \mathrm{O}$ ), and DMTMM (18.26 $\mathrm{mg}$ in $\left.350 \mu \mathrm{L}\right)$ were added to PGA $(6.61 \mathrm{mg}$ in $350 \mu \mathrm{L})$ every $30 \mathrm{~min}$ in three aliquots. The $\mathrm{pH}$ of the reaction mixture was adjusted to 8 . After $24 \mathrm{~h}, \operatorname{ArgOCH}_{3}(2 \mathrm{mg})$ and DMTMM $(18 \mathrm{mg})$ were added to the solution (during $30 \mathrm{~min}$ ). The reaction mixture was stirred at r.t. for $24 \mathrm{~h}$.

The polymer was isolated with Sephadex G-15 column chromatography. The various fractions collected were examined using TLC, (eluent $\mathrm{PrOH} / \mathrm{AcOEt} / \mathrm{H}_{2} \mathrm{O} / \mathrm{NH}_{3}$ 5:2:3:1). The main product was characterised by NMR spectroscopy.

${ }^{1} \mathrm{H}$ NMR (500, in $\left.\mathrm{D}_{2} \mathrm{O}\right) \delta$ (ppm): 5.20-4.80 (H-1 of CyD); 4.28 (s, CH Glu); $4.2(\mathrm{~m}, \mathrm{CH}$ Arg); 4.2-3.2 (m, H-3, -6, -5, -2,-4 of $\left.\mathrm{CyD}, \mathrm{OCH}_{3}\right) ; 3.2\left(\mathrm{~m}, \gamma \mathrm{CH}_{2} \mathrm{Arg}\right) ; 2.60-1.50(\mathrm{~m}, \beta$ - and $\gamma-\mathrm{CH}_{2}$ PGA); 1.35 (m, $\mathrm{CH}_{2}$ butyl chain of PGA); $1.26\left(\mathrm{~m}, \mathrm{CH}_{2}\right.$ butyl chain of PGA), $0.88(\mathrm{~m}$, $\mathrm{CH}_{3}$ butyl chain of PGA).

${ }^{13} \mathrm{C}$ NMR $\left(125 \mathrm{MHz}\right.$, in $\left.\mathrm{D}_{2} \mathrm{O}\right) \delta$ (ppm): 24.5 ( $\beta-\mathrm{CH}_{2}$ of $\mathrm{Arg}$ ), $26.8\left(\alpha-\mathrm{CH}_{2}\right.$ of $\mathrm{Arg}$ ), 31.8 ( $\beta-\mathrm{CH}_{2}$ of PGA), $40.5\left(\delta \mathrm{CH}_{2}\right.$ butyl chain of PGA), $52.3(\mathrm{CH} \mathrm{Arg}), 52.9(\mathrm{C}-2$ of $\mathrm{CyD}$ and $\mathrm{OCH}_{3}$ of $\mathrm{Arg}$ ), 53.0 (CH of Glu), 60.0 (C-6 of CyD), 71.6 (C-3 of CyD ), 73.0 (C-5 of CyD), 80.4 (C-4 of CyD), 101-105 (C-1 of CyD), 160 (C=N of Arg), 173-174 (CNH PGA-CyD, PGA-Arg), 174.72 (CO methyl ester of Arg).

Dimension (DLS, Z average): $49 \pm 5$; PDI (DLS): 0.4; Zeta potential: $8 \pm 1 \mathrm{mV}(\mathrm{pH}=7.4$ ).

The other polymers were synthesised in the same manner as PGA $\beta C y D A r g 1$ with different amounts of the reagents.

\subsubsection{Synthesis of PGA $\beta C y D A r g 2$}

The synthesis was carried out as described above with PGA (7 mg), DMTMM (18 mg), $\operatorname{ArgOCH} 3(6 \mathrm{mg}), \mathrm{DMTMM}(10 \mathrm{mg})$ and $\beta \mathrm{CyD} 3 \mathrm{NH}_{2}(50 \mathrm{mg})$.

${ }^{1} \mathrm{H}$ NMR (500 MHz, in $\mathrm{D}_{2} \mathrm{O}$ ) $\delta$ (ppm): 5.16-4.75 (H-1 of CyD); 4.28 (s, CH Glu); 4.20 (m, CH Arg); 4.10-3.20 (m, H-3, -6, -5, -2, -4 of CyD, $\left.\mathrm{OCH}_{3}\right) ; 3.13$ (m, $\left.\gamma-\mathrm{CH}_{2} \mathrm{Arg}\right) ; 2.58-1.60$ (m, $\gamma-\mathrm{CH}_{2}$ PGA,); 1.35 (m, $\mathrm{CH}_{2}$ butyl chain of PGA), $1.6\left(\mathrm{~m}, \mathrm{CH}_{2}\right.$ butyl chain of PGA ); 1.28 ( $\mathrm{m}, \mathrm{CH}_{2}$ butyl chain of PGA), 0.89 ( $\mathrm{m}, \mathrm{CH}_{3}$ butyl chain of PGA).

Dimension (DLS, Z average): $35 \pm 2 \mathrm{~nm}$; PDI (DLS): 0.5; Zeta potential: $7.7 \pm 0.5 \mathrm{mV}$ $(\mathrm{pH}=7.4)$.

\subsubsection{Synthesis of PGA $\gamma$ CyDArg3}

The synthesis was carried out as for PGA $\beta$ CyDArg2 with PGA (10 mg), DMTMM $(19 \mathrm{mg}), \mathrm{ArgOCH}_{3}(8 \mathrm{mg}), \mathrm{DMTMM}(20 \mathrm{mg})$ and $\gamma \mathrm{CyDNH}_{2}(67 \mathrm{mg})$.

${ }^{1} \mathrm{H}$ NMR (500 MHz, in $\left.\mathrm{D}_{2} \mathrm{O}\right) \delta$ (ppm): 5.20-4.77 (m, H-1 of CyD); 4.32 (m, CH Arg); 4.23 (s, CH Glu); 4.12 (m, H-3A of CyD); 3.93-3.49 (m, H-3, -6, -5, -2, -4 of CyD and $\mathrm{OCH}_{3}$ of $\mathrm{Arg}$ ); $3.12\left(\gamma-\mathrm{CH}_{2} \mathrm{Arg}\right) ; 2.57-1.45$ ( $\beta$ - and $\delta-\mathrm{CH}_{2}$ PGA, $\left.\mathrm{CH}_{2} \mathrm{Arg}\right) ; 1.38\left(\mathrm{~m}, \mathrm{CH}_{2}\right.$ butyl chain of PGA), 1.21 (m, $\mathrm{CH}_{2}$ butyl chain of PGA); 0.77 ( $\mathrm{m}, \mathrm{CH}_{3}$ butyl chain of PGA).

Dimension (DLS, $\mathrm{Z}$ average): $29 \pm 3 \mathrm{~nm}$; PDI (DLS): 0.4; Zeta potential: $2.3 \pm 0.5 \mathrm{mV}$ $(\mathrm{pH}=7.4)$.

\subsubsection{Synthesis of PGA $\beta C y D A r g 4$ and PGA $\gamma$ CDArg5}

The synthesis was carried out as described above with PGA (25 mg), DMTMM (48 mg), $\mathrm{ArgOCH}_{3}(33 \mathrm{mg})$, DMTMM $(21 \mathrm{mg})$ and $\mathrm{BCyD}_{3} \mathrm{NH}_{2}(59 \mathrm{mg})$ or $\gamma \mathrm{CyD} 3 \mathrm{NH}_{2}(72 \mathrm{mg})$.

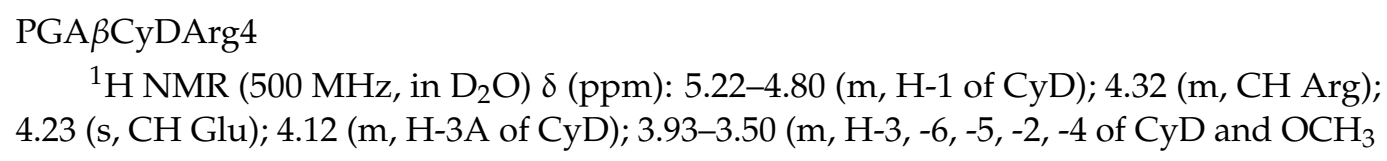

${ }^{1} \mathrm{H}$ NMR (500 MHz, in $\mathrm{D}_{2} \mathrm{O}$ ) $\delta$ (ppm): 5.22-4.80 (m, H-1 of CyD); 4.32 (m, CH Arg); 4.23 (s, CH Glu); 4.12 (m, H-3A of CyD); 3.93-3.50 (m, H-3, -6, -5, -2, -4 of CyD and $\mathrm{OCH}_{3}$ 
of Arg); $3.12\left(\gamma-\mathrm{CH}_{2} \mathrm{Arg}\right) ; 2.60-1.49$ ( $\beta$ - and $\left.\delta-\mathrm{CH}_{2} \mathrm{PGA}, \mathrm{CH}_{2} \mathrm{Arg}\right) ; 1.39\left(\mathrm{~m}, \mathrm{CH}_{2}\right.$ butyl chain of PGA), $1.20\left(\mathrm{~m}, \mathrm{CH}_{2}\right.$ butyl chain of PGA); 0.78 (m, $\mathrm{CH}_{3}$ butyl chain of PGA).

${ }^{13} \mathrm{C}$ NMR $\left(125 \mathrm{MHz}\right.$, in $\left.\mathrm{D}_{2} \mathrm{O}\right) \delta(\mathrm{ppm}): 24.4\left(\beta-\mathrm{CH}_{2}\right.$ of $\left.\mathrm{Arg}\right), 27.6\left(\alpha-\mathrm{CH}_{2}\right.$ of $\left.\mathrm{Arg}\right), 31.3$ ( $\beta-\mathrm{CH}_{2}$ of PGA), $40.5\left(\delta \mathrm{CH}_{2}\right.$ butyl chain of PGA), $52.34(\mathrm{CH} \mathrm{Arg}), 52.8(\mathrm{C}-2$ of $\mathrm{CyD}$ and $\mathrm{OCH}_{3}$ of Arg), 52.9 (CH of Glu), 60.0 (C-6 of CyD), 71.4 (C-3 of CyD), 72.5 (C-5 of CyD), 80.3 (C-4 of CyD), 101. 7 (C-1 of CyD), 160 (C=N of Arg), 173-174 (C-NH PGA-CyD, PGA-Arg), 174.7 (CO methyl ester of Arg).

Dimension (DLS, Z average): $79 \pm 8 \mathrm{~nm}$; PDI (DLS): 0.6; Zeta potential: $45 \pm 5 \mathrm{mV}$ $(\mathrm{pH}=7.4)$.

\section{PGA $\gamma$ CyDArg5}

${ }^{1} \mathrm{H}$ NMR (500 MHz, in $\left.\mathrm{D}_{2} \mathrm{O}\right) \delta$ (ppm): 5.22-4.70 (m, H-1 of CyD); 4.32 (m, CH Arg); 4.23 (s, CH Glu); 4.12 (m, H-3-A of CyD); 4.05-3.32 (m, H-3, -6, -5, -2, -4 of CyD and $\mathrm{OCH}_{3}$ of $\mathrm{Arg}) ; 3.12\left(\gamma-\mathrm{CH}_{2} \mathrm{Arg}\right) ; 2.59-1.46$ ( $\beta$ - and $\left.\delta-\mathrm{CH}_{2} \mathrm{PGA}, \mathrm{CH}_{2} \mathrm{Arg}\right) ; 1.37\left(\mathrm{~m}, \mathrm{CH}_{2}\right.$ butyl chain of PGA), 1.21 (m, $\mathrm{CH}_{2}$ butyl chain of PGA); 0.78 (m, $\mathrm{CH}_{3}$ butyl chain of PGA).

${ }^{13} \mathrm{C}$ NMR $\left(125 \mathrm{MHz}\right.$, in $\left.\mathrm{D}_{2} \mathrm{O}\right) \delta$ (ppm): $24.4\left(\beta-\mathrm{CH}_{2}\right.$ of $\left.\mathrm{Arg}\right), 27.7\left(\alpha-\mathrm{CH}_{2}\right.$ of $\left.\mathrm{Arg}\right), 31.3$ ( $\beta-\mathrm{CH}_{2}$ of PGA), $40.4\left(\delta \mathrm{CH}_{2}\right.$ butyl chain of PGA), $52.4(\mathrm{CH} \mathrm{Arg}), 52.8(\mathrm{C}-2$ of $\mathrm{CyD}$ and $\mathrm{OCH}_{3}$ of Arg), 52.9 (CH of Glu), 60.0 (C-6 of CyD), 71.5 (C-3 of CyD), 72.0 (C-5 of CyD), 80.4 (C-4 of CyD), 101. 7 (C-1 of CyD), 160 (C=N of Arg), 173-174 (CNH PGA-CyD, PGA-Arg), 174.72 (CO methyl ester of Arg).

Dimension (DLS, Z average): $59 \pm 6 \mathrm{~nm}$; PDI (DLS): 0.6; Zeta potential: $37 \pm 3 \mathrm{mV}$ $(\mathrm{pH}=7.4)$.

\subsection{Instrumentation}

${ }^{1} \mathrm{H}$ and ${ }^{13} \mathrm{C}$ NMR spectra were recorded at $25^{\circ} \mathrm{C}$ with a VARIAN UNITY PLUS-500 spectrometer at 499.9 and $125.7 \mathrm{MHz}$, respectively, using Varian library standard pulse programs. All samples were prepared in deuterated solvents $\left(\mathrm{D}_{2} \mathrm{O}\right) ;{ }^{1} \mathrm{H}$ NMR spectra were referred to the HOD signal and ${ }^{13} \mathrm{C}$ NMR spectra to acetone (external reference). In all the experiments, the pulse at $90^{\circ}$ lasted about $7 \mu \mathrm{s}$. 2D experiments (COSY, HSQC and HMBC) were acquired using $1 \mathrm{~K}$ data points and 256 increments.

UV-Vis spectra were recorded with a VersaWave microvolume UV/Vis spectrophotometer (Expedeon, Ottawa, ON, Canada). The molar absorptivity of DOX $10,410\left(\mathrm{~mol}^{-1} \mathrm{~L} \mathrm{~cm}^{-1}\right)$ at $482 \mathrm{~nm}$ was used.

\subsubsection{Dynamic Light Scattering and Zeta Potential Measurements}

Dynamic light scattering (DLS) and zeta potential (ZP) measurements were performed at $25^{\circ} \mathrm{C}$ with a Zetasizer Nano ZS (Malvern Instruments, Oxford, UK) operating at $633 \mathrm{~nm}$ (He-Ne laser). The mean hydrodynamic diameter (d) of the NPs was calculated from intensity measurement after averaging the five measurements. The samples $(1 \mathrm{mg} / \mathrm{mL})$ were diluted in phosphate buffer $(\mathrm{pH}=7.4)$ prepared in ultrapure water filtered $(0.2 \mu \mathrm{m})$.

\subsubsection{Mass Spectrometry}

MALDI-TOF MS experiments were performed using an AB SCIEX MALDI-TOF/TOF 5800 Analyzer (AB SCIEX, Foster City, CA, USA) equipped with a nitrogen UV laser $(\lambda=337 \mathrm{~nm})$ pulsed at a $20 \mathrm{~Hz}$ frequency by using a set up previously described [26]. Briefly, the mass spectrometer operated in the linear mode and the laser intensity set above the ionisation threshold (4500 in arbitrary units). Mass spectra were processed using Data Explorer 4.11 software (Applied Biosystems, Warrington, UK). 2,5-di-hydroxybenzoic acid (DHB) was used as the matrix, dissolved in water/acetonitrile $1: 1$ containing $0.03 \%$ of $\mathrm{CF}_{3} \mathrm{COOH}$. Molar-mass averages $\left(\mathrm{M}_{\mathrm{n}}\right.$ and $\left.\mathrm{M}_{\mathrm{w}}\right)$ values were also calculated using Data Explorer software (Applied Biosystems, Warrington, UK). 


\subsection{Cell Culture and Antiproliferative Assay}

A2780 (ovarian carcinoma), A549 (lung carcinoma) and MDA-MB-231 (breast carcinoma) cells (all obtained from ICLC, Genova, Italy) were grown as monolayers in Roswell Park Memorial Institute (RPMI 1640) or Dulbecco's Modified Eagle's Medium (DMEM) media (EuroClone, Pero, Italy) supplemented with $10 \%$ fetal bovinum serum (FBS) (Euroclone), antibiotics (EuroClone), and non-essential amino-acids (only DMEM, EuroClone). For the assay, cells plated into flat-bottomed 96-well microtiter plates were treated after 6-8 $\mathrm{h}$ with the complexes (five 1:5 scalar solutions, $20 \mu \mathrm{L}$, starting from $1 \mu \mathrm{M}$ concentration). Seventy-two hours later, cells were analysed by the 3-(4,5-dimethylthiazol-2-yl)-2,5diphenyltetrazolium Bromide (MTT) assay as described elsewhere [33].

$\mathrm{IC}_{50}$ values were calculated from the analysis of single concentration-response curves. Final values are the mean of 4-12 experiments.

\subsection{A $\beta$ Aggregation Assay}

The antiaggregant effect of the newly synthesised compounds on the self-induced aggregation process of $A \beta$ was assayed as previously reported [32]. Briefly, $A \beta(20 \mu \mathrm{M})$, ThT $(60 \mu \mathrm{M})$ and the compounds of interest were incubated in phosphate buffered saline $(\mathrm{pH}$ 7.4) at $37^{\circ} \mathrm{C}$ in a multiplate reader (Varioskan Flash, Thermo Scientific, Leiden, The Netherlands). The fluorimetric readings (excitation and emission wavelengths were $450 \mathrm{~nm}$ and $480 \mathrm{~nm}$, respectively) were collected every $10 \mathrm{~min}$ up to $60 \mathrm{~h}$. Data of all the measurements, carried out in triplicate, were fitted to Equation (1).

$$
F(t)=F_{0}+\frac{F_{\max }-F_{0}}{1+e^{\frac{t-t}{k}}}
$$

$F_{\max }-F_{0}$ is the higher fluorescence increment recorded all over the aggregation process; the lag phase $\left(t_{\text {lag }}\right)$ is the time interval preceding the formation of amyloid-type species sensitive to ThT. The $t_{\text {lag }}$ values were calculated by using Equation (2)

$$
t_{\text {lag }}=t-2 / k
$$

The parameters of each set of measurements were expressed as the mean $\pm \mathrm{SD}$.

\subsection{Solubility Experiments}

DOX hydrochloride $(0.017 \mathrm{M}$, water solution) was added to the solutions containing different concentrations $(25 \mathrm{mg} / \mathrm{mL}, 12 \mathrm{mg} / \mathrm{ML}, 6 \mathrm{mg} / \mathrm{mL})$ of all the polymers in phosphate buffer ( $50 \mathrm{mM}, \mathrm{pH} 7.4)$. The suspensions were sonicated for $3 \mathrm{~min}$, incubated at $25^{\circ} \mathrm{C}$ in the dark and centrifugated after $2 \mathrm{~h}$. DOX was determined in the supernatant with $\mathrm{UV} /$ Vis spectroscopy, at $482 \mathrm{~nm}$.

\subsection{Statistical Analysis}

For statistical analysis the one way ANOVA was used followed by the post-hoc Bonferroni/Dunn analysis of data.

Supplementary Materials: The following are available online, Figures S1-S11: NMR spectra of the polymers, Figure S12: MALDI-TOF MS spectra of the PGACyDArg polymers, Figure S13: Solubility of DOX in the presence of the PGACyDArg polymers.

Author Contributions: Conceptualisation, G.V., methodology, N.B. (Noemi Bognanni), F.B., M.V., N.B. (Nadia Bertola), G.V.; formal analysis, N.B. (Noemi Bognanni); investigation, G.V., N.B. (Noemi Bognanni), F.B., N.B. (Nadia Bertola) and M.V.; data curation, G.V., N.B. (Noemi Bognanni), F.B., N.B. (Nadia Bertola) and M.V.; writing — original draft preparation, G.V., N.B. (Noemi Bognanni), F.B., and M.V.; writing-review and editing, G.V., N.B. (Noemi Bognanni), F.B. and M.V.; project administration, G.V., funding acquisition, M.V. and G.V. All authors have read and agreed to the published version of the manuscript.

Funding: This research received no external funding. 
Institutional Review Board Statement: Not applicable.

Informed Consent Statement: Not applicable.

Data Availability Statement: Please refer to suggested Data Availability Statements in the section "MDPI Research Data Policies" at https://www.mdpi.com/ethics.

Acknowledgments: The authors acknowledge support from Università degli Studi di Catania (Piano di incentivi per la ricerca di Ateneo 2020/2022 (Pia.ce.ri.) and from Italian Ministry of Health (Ricerca Corrente).

Conflicts of Interest: The authors declare no conflict of interest.

$\begin{array}{ll}\text { Abbreviations } & \\ \text { A2780 } & \text { Human ovarian carcinoma } \\ \text { A549 } & \text { Human Caucasian lung carcinoma } \\ \text { A } \beta & \text { Amyloid beta } \\ \text { AD } & \text { Alzheimer's disease ArgOCH } 3 \text {, arginine methyl ester } \\ \text { CyD } & \text { Cyclodextrin } \\ \text { CTRL } & \text { control } \\ \text { DHB } & \text { 2,5-di-hydroxybenzoic acid } \\ \text { DLS } & \text { Dynamic light scattering } \\ \text { DMEM } & \text { Dulbecco's Modified Eagle's Medium } \\ \text { DMTMM } & \text { 4-(4,6-Dimethoxy-1,3,5-triazin 2-yl)-4-methylmorpholinium chloride } \\ \text { DOX } & \text { Doxorubicin F } \\ \text { FBS } & \text { Fetal Bovinum Serum } \\ \text { IC } 50 & \text { half maximal inhibitory concentration } \\ \text { MTT } & \text { 3-(4,5-dimethylthiazol-2-yl)-2,5-diphenyltetrazolium Bromide } \\ \text { MDA-MB-231 } & \text { Human Caucasian breast adenocarcinoma } \\ \text { PGA } & \text { N-butyl-polyglutamate } \\ \text { PGACyDArg } & \text { N-butyl-polyglutamate Cyclodextrin Arginine } \\ \text { RPMI } & \text { Roswell Park Memorial Institute } \\ \text { ThT } & \text { Thioflavin T }\end{array}$

\section{References}

1. Oliveri, V.; Vecchio, G. Metallocyclodextrins in Medicinal Chemistry. Future Med. Chem. 2018, 10, 663-677. [CrossRef]

2. Jansook, P.; Ogawa, N.; Loftsson, T. Cyclodextrins: Structure, Physicochemical Properties and Pharmaceutical Applications. Int. J. Pharm. 2018, 535, 272-284. [CrossRef] [PubMed]

3. Muankaew, C.; Loftsson, T. Cyclodextrin-Based Formulations: A Non-Invasive Platform for Targeted Drug Delivery. Basic Clin. Pharmacol. Toxicol. 2018, 122, 46-55. [CrossRef]

4. Garrido, P.F.; Calvelo, M.; Blanco-González, A.; Veleiro, U.; Suárez, F.; Conde, D.; Cabezón, A.; Piñeiro, Á.; Garcia-Fandino, R. The Lord of the NanoRings: Cyclodextrins and the Battle against SARS-CoV-2. Int. J. Pharm. 2020, 588. [CrossRef]

5. Jacob, S.; Nair, A.B. Cyclodextrin Complexes: Perspective from Drug Delivery and Formulation. Drug Dev. Res. 2018, $79,201-217$. [CrossRef] [PubMed]

6. Santos, A.C.; Costa, D.; Ferreira, L.; Guerra, C.; Pereira-Silva, M.; Pereira, I.; Peixoto, D.; Ferreira, N.R.; Veiga, F. CyclodextrinBased Delivery Systems for in Vivo-Tested Anticancer Therapies. Drug Deliv. Transl. Res. 2021, 11, 49-71. [CrossRef]

7. Zhang, D.; Lv, P.; Zhou, C.; Zhao, Y.; Liao, X.; Yang, B. Cyclodextrin-Based Delivery Systems for Cancer Treatment. Mater. Sci. Eng. C 2019, 96, 872-886. [CrossRef]

8. Hoang Thi, T.T.; Du Cao, V.; Nguyen, T.N.Q.; Hoang, D.T.; Ngo, V.C.; Nguyen, D.H. Functionalized Mesoporous Silica Nanoparticles and Biomedical Applications. Mater. Sci. Eng. C 2019, 99, 631-656. [CrossRef]

9. Xu, S.; Wang, P.; Sun, Z.; Liu, C.; Lu, D.; Qi, J.; Ma, J. Dual-Functionalization of Polymeric Membranes via Cyclodextrin-Based Host-Guest Assembly for Biofouling Control. J. Memb. Sci. 2019, 569, 124-136. [CrossRef]

10. Kulkarni, A.; Caporali, P.; Dolas, A.; Johny, S.; Goyal, S.; Dragotto, J.; Macone, A.; Jayaraman, R.; Fiorenza, M.T. Linear Cyclodextrin Polymer Prodrugs as Novel Therapeutics for Niemann-Pick Type C1 Disorder. Sci. Rep. 2018, 8, 9547. [CrossRef]

11. Liao, R.; Lv, P.; Wang, Q.; Zheng, J.; Feng, B.; Yang, B. Cyclodextrin-Based Biological Stimuli-Responsive Carriers for Smart and Precision Medicine. Biomater. Sci. 2017, 5, 1736-1745. [CrossRef]

12. van de Manakker, F.; Vermonden, T.; van Nostrum, C.F.; Hennink, W.E. Cyclodextrin-Based Polymeric Materials: Synthesis, Properties, and Pharmaceutical/Biomedical Applications. Biomacromolecules 2009, 10, 3157-3175. [CrossRef] 
13. Heidel, J.D.; Schluep, T. Cyclodextrin-Containing Polymers: Versatile Platforms of Drug Delivery Materials. J. Drug Deliv. 2012, 2012, 1-17. [CrossRef] [PubMed]

14. Serno, T.; Geidobler, R.; Winter, G. Protein Stabilization by Cyclodextrins in the Liquid and Dried State. Adv. Drug Deliv. Rev. 2011, 63, 1086-1106. [CrossRef]

15. Otzen, D.E.; Knudsen, B.R.; Aachmann, F.; Larsen, K.L.; Wimmer, R. Structural Basis for Cyclodextrins' Suppression of Human Growth Hormone Aggregation. Protein Sci. 2009, 11, 1779-1787. [CrossRef] [PubMed]

16. Oliveri, V.; Vecchio, G. Cyclodextrins as Protective Agents of Protein Aggregation: An Overview. Chem. Asian J. 2016, 11, 1648-1657. [CrossRef] [PubMed]

17. Oliveri, V.; Bellia, F.; Pietropaolo, A.; Vecchio, G. Unusual Cyclodextrin Derivatives as a New Avenue to Modulate Self- and Metal-Induced A $\beta$ Aggregation. Chem. Eur. J. 2015, 21, 14047-14059. [CrossRef]

18. Wahlström, A.; Cukalevski, R.; Danielsson, J.; Jarvet, J.; Onagi, H.; Rebek, J.; Linse, S.; Gräslund, A. Specific Binding of a $\beta$-Cyclodextrin Dimer to the Amyloid $\beta$ Peptide Modulates the Peptide Aggregation Process. Biochemistry 2012, 51, 4280-4289. [CrossRef] [PubMed]

19. Wang, Z.; Chang, L.; Klein, W.L.; Thatcher, G.R.J.; Venton, D.L. Per-6-Substituted-per-6-Deoxy $\beta$-Cyclodextrins Inhibit the Formation of $\beta$-Amyloid Peptide Derived Soluble Oligomers. J. Med. Chem. 2004, 47, 3329-3333. [CrossRef]

20. Giglio, V.; Bellia, F.; Oliveri, V.; Vecchio, G. Aminocyclodextrin Oligomers as Protective Agents of Protein Aggregation. Chempluschem 2016, 81, 660-665. [CrossRef] [PubMed]

21. Zou, S.; Wang, X.; Liu, P.; Ke, C.; Xu, S. Arginine Metabolism and Deprivation in Cancer Therapy. Biomed. Pharmacother. 2019, 118, 109210. [CrossRef]

22. Fuchs, S.M.; Rutkoski, T.J.; Kung, V.M.; Groeschl, R.T.; Raines, R.T. Increasing the Potency of a Cytotoxin with an Arginine Graft. Protein Eng. Des. Sel. 2007, 20, 505-509. [CrossRef]

23. Mizusako, H.; Tagami, T.; Hattori, K.; Ozeki, T. Active Drug Targeting of a Folate-Based Cyclodextrin-Doxorubicin Conjugate and the Cytotoxic Effect on Drug-Resistant Mammary Tumor Cells In Vitro. J Pharm Sci 2015, 104, 2934-2940. [CrossRef]

24. Viale, M.; Vecchio, G.; Monticone, M.; Bertone, V.; Giglio, V.; Maric, I.; Cilli, M.; Bocchini, V.; Profumo, A.; Ponzoni, M.; et al. Fibrin Gels Entrapment of a Poly-Cyclodextrin Nanocarrier as a Doxorubicin Delivery System in an Orthotopic Model of Neuroblastoma: Evaluation of In Vitro Activity and In Vivo Toxicity. Pharm. Res. 2019, 36, 1-12. [CrossRef]

25. Tian, B.; Hua, S.; Liu, J. Cyclodextrin-Based Delivery Systems for Chemotherapeutic Anticancer Drugs: A Review. Carbohydr. Polym. 2020, 232, 115805. [CrossRef]

26. Oliveri, V.; Bellia, F.; Viale, M.; Maric, I.; Vecchio, G. Linear Polymers of $\beta$ and $\gamma$ Cyclodextrins with a Polyglutamic Acid Backbone as Carriers for Doxorubicin. Carbohydr. Polym. 2017, 177, 355-360. [CrossRef] [PubMed]

27. Giachino, C.; Viale, M.; Vecchio, G. Exploring the Functionalization of Polymeric Nanoparticles Based on Cyclodextrins for Tumor Cell Targeting. ChemistrySelect 2019, 4, 13025-13028. [CrossRef]

28. Haass, C.; Selkoe, D.J. Soluble Protein Oligomers in Neurodegeneration: Lessons from the Alzheimer's Amyloid $\beta$-Peptide. Nat. Rev. Mol. Cell Biol. 2007, 8, 101-112. [CrossRef]

29. Greco, V.; Naletova, I.; Ahmed, I.M.M.; Vaccaro, S.; Messina, L.; La Mendola, D.; Bellia, F.; Sciuto, S.; Satriano, C.; Rizzarelli, E. Hyaluronan-Carnosine Conjugates Inhibit A $\beta$ Aggregation and Toxicity. Sci. Rep. 2020, 10, 1-14. [CrossRef] [PubMed]

30. Anand, R.; Malanga, M.; Manet, I.; Manoli, F.; Tuza, K.; Aykaç, A.; Ladavière, C.; Fenyvesi, E.; Vargas-Berenguel, A.; Gref, R.; et al. Citric Acid- $\gamma$-Cyclodextrin Crosslinked Oligomers as Carriers for Doxorubicin Delivery. Photochem. Photobiol. Sci. 2013, 12, 1841-1854. [CrossRef] [PubMed]

31. Giglio, V.; Viale, M.; Bertone, V.; Maric, I.; Vaccarone, R.; Vecchio, G. Cyclodextrin Polymers as Nanocarriers for Sorafenib. Investig. New Drugs 2018, 36, 370-379. [CrossRef] [PubMed]

32. Grasso, G.I.; Bellia, F.; Arena, G.; Satriano, C.; Vecchio, G.; Rizzarelli, E. Multitarget Trehalose-Carnosine Conjugates Inhibit A $\beta$ Aggregation, Tune Copper(II) Activity and Decrease Acrolein Toxicity. Eur. J. Med. Chem. 2017, 135, 447-457. [CrossRef] [PubMed]

33. Viale, M.; Cordazzo, C.; de Totero, D.; Budriesi, R.; Rosano, C.; Leoni, A.; Ioan, P.; Aiello, C.; Croce, M.; Andreani, A.; et al. Inhibition of MDR1 Activity and Induction of Apoptosis by Analogues of Nifedipine and Diltiazem: An in Vitro Analysis. Investig. New Drugs 2011, 29, 98-109. [CrossRef] [PubMed] 